\title{
PENGARUH BIMBINGAN KELOMPOK TERHADAP REGULASI EMOSI REMAJA DI LINGKUNGAN XI RAMBUNG PUTIH SIMPANG MANCANG KELURAHAN PEKAN SELESAI KABUPATEN LANGKAT
}

\author{
${ }^{1}$ Maya Rizky Miraza, ${ }^{2}$ Sari Wardani Simarmata, ${ }^{3}$ Ahmad Azrai \\ Azis \\ ${ }^{1}$ Mahasiswa STKIP Budidaya Binjai \\ ${ }^{1}$ rizky_ananda2@yahoo.com, \\ ${ }^{2,3}$ Dosen STKIP Budidaya Binjai \\ ${ }_{2}^{2}$ sari.sarwa24@gmail.com
}

\begin{abstract}
ABSTRAK
Tujuan penelitian ini adalah untuk mengetahui pengaruh bimbingan kelompok terhadap regulasi emosi remaja di Lingkungan XI Rambung Putih Simpang Mancang Kelurahan Pekan Selesai Kabupaten Langkat. Jenis penelitian ini merupakan penelitian eksperimen dengan desain one group pretest-posttest design. Jumlah sampel penelitian ini sebanyak 8 orang. Instrumen pengumpulan data dalam penelitian ini menggunakan angket regulasi emosi. Berdasarkan hasil penelitian dapat diambil kesimpulan yaitu terdapat pengaruh bimbingan kelompok terhadap regulasi emosi remaja di Lingkungan XI Rambung Putih Simpang Mancang Kelurahan Pekan Selesai Kabupaten Langkat. Hal itu ditunjukkan dengan lebih besarnya nilai t hitung dari pada t tabel yaitu $3,8>1,94$.
\end{abstract}

Kata Kunci : Bimbingan Kelompok, Regulasi Emosi, Remaja.

\begin{abstract}
The purpose of this study was to determine the effect of group guidance on the emotional regulation of adolescents in the XI Rambung Putih Simpang Mancang Environment, Pekan Selesai, Langkat District. This type of research is an experimental study with a one group pretest-posttest design. The number of samples in this study were 8 people. The data collection instrument in this study used an emotional regulation questionnaire. Based on the results of the study, it can be concluded that there is an effect of group guidance on the regulation of adolescent emotions in the XI Rambung Putih Simpang Mancang Environment, Pekan Selesai Village, Langkat Regency. This is indicated by the greater value of t count than t table, namely 3.8>1.94.
\end{abstract}

Keywords: Group Guidance, Emotion Regulation, Youth. 


\section{Jurnal Serunai Bimbingan dan Konseling \\ Vol 9, No. 2, Oktober 2020 \\ e-ISSN 2655-223X}

\section{PENDAHULUAN}

Masa remaja merupakan masa peralihan dari anak-anak menuju dewasa yang ditinjau berdasarkan batasan usia dan merupakan salah satu tahap perkembangan dalam rentang kehidupan manusia. Remaja merupakan aset sumber daya manusia yang mempunyai peranan yang vital sebagai generasi penerus bangsa dimasa yang akan datang (Simarmata dan Citra, 2020:17). Menurut Herlina (2016: 55) "keremajaan merupakan gejala sosial yang bersifat sementara". Sifat kesementaraan tersebut adalah karena adanya batasan usia pada masa remaja. Menurut Desmita,(2010:37) batas usia pada masa remaja adalah 12 tahun sampai 21 tahun. Pada masa remaja banyak perubahan yang terjadi pada setiap individu yang memasuki masa tersebut. Perubahan tersebut meliputi semua aspek perkembangan seperti perubahan fisik, emosional, sosial, moral, dan juga kepribadian (Hurlock seperti dikutip Lubis, 2017:44). Hubungan teman sebaya yang baik diperlukan bagi perkembangan sosial yang normal pada masa remaja, karena pada masa ini remaja akan mengembangkan sikapnya dalam berinteraksi dengan lingkuan sosialnya (Rahayu, 2013:39). Contoh hubungan sosial yang baik pada remaja adalah saling menolong, aktif dalam kegiatan masyarakat, aktif dalam kegiatan remaja seperti dalam organisasi remaja masjid, mematuhi perintah orang tua dan sebagainya. Kemudian contoh hubungan sosial yang tidak baik pada remaja atau persoalan-persoalan yang sering terjadi pada remaja dalam rutinitas sehari-hari menurut Masqood (seperti dikutip Diananda, 2018:126127) adalah mencuri, berbohong, mengucapkan kata-kata yang cenderung vulgar, tidak patuh dan suka membantah, selalu menolak apabila diperintahkan, suka berdebat, bergaul dengan orang tidak jelas orientasi hidupnya, melalaikan pelajaran agamanya atau tidak memperhatikan ibadahnya seperti tidak sholat.

Perilaku sosial remaja, erat kaitannya dengan emosi pada remaja itu sendiri. Menurut Sunarto dan Hartono (2013:26) emosi merupakan "gejala perasaan disertai dengan perubahan atau perilaku fisik. Seperti marah yang ditunjukkan dengan teriakan suara keras, atau tingkah laku yang lain. Begitu pula sebaliknya seorang yang gembira akan melonjak-lonjak sambil tertawa lebar, dan sebagainya". Artinya emosi itu muncul pada diri remaja atau individu disebabkan oleh adanya suatu perlakuan atau kondisi yang dialami oleh remaja. Untuk dapat mengontrol emosi yang muncul akibat dari suatu perlakukan diperlukan regulasi emosi yang baik.

Regulasi emosi adalah strategi yang dilakukan secara sadar ataupun tidak sadar untuk mempertahankan, memperkuat atau mengurangi satu atau lebih aspek dari respon emosi yaitu pengalaman emosi dan perilaku. Menurut Gross dalam Anggreiny (2014:22) "seseorang yang memiliki regulasi emosi dapat mempertahankan atau meningkatkan emosi yang dirasakan baik positif maupun negatif'. Kemudian, menurut Sulistyo (2014:3) regulasi emosi adalah "kemampuan individu untuk memonitor, mengevaluasi dan memodifikasiemosi yang muncul untuk mencapai tujuan yang meliputi kemampuan mengatur perasaan, reaksi fisiologis, cara berfikir, dan respon emosi (ekspresi wajah, tingkah laku dan nada suara) sehingga dapat diekspresikan secara tepat dengan lingkungan".Seorang remaja yang memiliki regulasi emosi yang rendah sering kali menyebabkan terjadinya pertikaian, stres dan bahkan sampai mengalami depresi sedangkan remaja yang mampu mengelola emosinya akan membantu mereka mengatasi stres dalam 


\section{Jurnal Serunai Bimbingan dan Konseling \\ Vol 9, No. 2, Oktober 2020 \\ e-ISSN 2655-223X}

kehidupannya dan sebagai bekal kesehatan mental remaja dalam menghadapi kehidupan yang akan datang (Fitriani dan Alsa, 2015:150). Seorang remaja yang memiliki regulasi emosi yang tinggi akan dapat berperilaku dengan benar sesuai dengan keadaan atau kondisi yang dialaminya. Sedangkan remaja dengan regulasi emosi rendah akan menimbulkan dampak negatif dan ketidakmampuannya dalam mengendalikan emosi.

Ketidakmampuannya dalam

mengendalikan emosi disebabkan oleh kurangnya pemahaman emosi yang dirasakan dan kurangnya kemampuan memahami kejadian yang dialami sehingga menyebabkan kesulitan untuk modifikasi emosi dalam menyelesaikan masalah yang dihadapi. Oleh sebab itu, dapat dikatakan bahwa kemampuan regulasi emosi digunakan untuk menentukan perilaku atau sikap dalam menyikapi suatu persoalan. Regulasi emosi dapat bermanfaat untuk mengendalikan atau mengatur emosi yang muncul secara otomatis maupun spontan sebelum melakukan aksi dalam peristiwa atau persoalan tertentu. Selain itu, regulasi emosi sangat penting dalam kehidupan manusia untuk mereduksi ketegangan yang timbul saat emosi yang sedang memuncak. Hendrikson seperti dikutip Utomo (2018:19) mengemukakan emosi pada setiap individu dipengaruhi oleh berbagai faktor, begitu juga ketika individu harus mengatur kondisi emosinya. Faktor-faktor tersebut antara lain lingkungan, jenis kelamin, usia, pola asuh orang tua, pengalaman, dan pengalaman traumatik.

Berdasarkan hasil observasi dan wawancara dengan beberapa orang tua dan remaja yang telah dilakukan peneliti di Lingkungan XI Rambung Putih Simpang Mancang Kelurahan Pekan Selesai Kabupaten Langkat, ditemukan bahwa terdapat remaja yang belum mampu mengontrol emosinya sehingga menimbulkan pertikaian antara remaja, selain itu terdapat hubungan yang kurang baik antar teman sebaya, membantah orang yang lebih tua, kurang sopan, dan membully teman bermain yang lebih muda usianya. Fenomena tersebut menunjukkan bahwa regulasi emosi pada remaja di Lingkungan XI Rambung Putih Simpang Mancang Kelurahan Pekan Selesai Kabupaten Langkat perlu ditingkatkan, salah satunya yaitu dengan memberikan bimbingan kelompok, seperti yang telah dijelaskan di atas.

Mengoptimalkan kemampuan regulasi emosi pada remaja dapat ditempuh dengan memberikan bimbingan pada remaja sebagai peran dari bimbingan dan konseling. Menurut Nurihsan (2018:7) bimbingan merupakan upaya pembimbing untuk mengoptimalkan individu". Pengertian tersebut, juga dapat dimaknai sebagai upaya yang dilakukan oleh pembimbing untuk mengoptimalkan kemampuan regulasi emosi pada remaja. Salah satu bentuk layanan bimbingan sebagai upaya untuk mengoptimalkan kemampuanregulasi emosi pada remaja adalah layanan bimbingan kelompok.

Menurut Hartinah (2017:4) bimbingan kelompok adalah "bimbingan yang dilakukan secara kelompok terhadap sejumlah individu sekaligus sehingga dapat menerima bimbingan yang dimaksudkan”. Kemudian, menurut Rusman (2009:13) bahwa bimbingan kelompok adalah proses pemberian bantuan kepada individu melalui dinamika kelompok dengan berbagi pengalaman dalam upaya pengembanganwawasan, sikap dan/atau keterampilan yangdiperlukan dalam upaya mencegahtimbulnya masalah atau dalam upayapengembangan pribadi. Menurut Romlah (2001:13) tujuan bimbingan kelompok adalah "untuk membantu individu 


\section{Jurnal Serunai Bimbingan dan Konseling \\ Vol 9, No. 2, Oktober 2020 \\ e-ISSN 2655-223X}

menemukan dirinya sendiri, mengarahkan dan dapat menyesuikan diri dengan lingkungannya". Menurut Prayitno seperti dikutip Utomo (2018:29) terdapat beberapa tahap-tahap dalam pelaksanaan bimbingan kelompok yaitu "tahap pembentukan, peralihan, kegiatan, dan pengakhiran”. Dengan demikian bimbingan kelompok dapat digunakan untuk memberikan pengarahan kepada remaja agar dapat mengoptimalkan kemampuan regulasi emosinya.

Rumusan masalah dalam penelitian ini adalah "Apakah terdapat pengaruh bimbingan kelompok terhadap regulasi emosi remaja di Lingkungan XI Rambung Putih Simpang Mancang Kelurahan Pekan Selesai Kabupaten Langkat ?". Tujuan yang ingin dicapai dalam penelitian ini yaitu untuk "mengetahui pengaruh bimbingan kelompok terhadap regulasi emosi remaja di Lingkungan XI Rambung Putih Simpang Mancang Kelurahan Pekan Selesai Kabupaten Langkat". Diharapkan hasil penelitian ini bermanfaat secara teoritis dan secara praktis. Manfaat teoritis dari hasil penelitian ini adalah dapat menambahkan konsep-konsep bimbingan, khususnya pada kajian bimbingan kelompok terhadap regulasi emosi remaja. Manfaat praktis penelitian ini dapat dijadikan sebagai suatu sumbangan informasi atau pemikiran bagi beberapa pihak, diantaranya: (a) Bagi Remaja, memberikan pengalaman kepada remaja dalam mengikuti bimbingan kelompok dan para remaja dapat mengetahui sejauh mana kemampuan regulasi emosinya saat menghadapi situasi sosial tertentu, sehingga dapat mempertahankan atau meningkatkan

kemampuan regulasi emosinya tersebut. (b) Bagi Orang Tua, orang tua dapat mengetahui kemampuan regulasi emosi anaknya, sehingga dapat menentukan sikap dalam membimbing anak agar mampu meregulasi emosinya. dan (c) Bagi Peneliti, melalui penelitian ini akan memberikan wawasan dan pengalaman tersendiri bagi peneliti dan semua yang membaca hasil penelitian ini dapat menjadikan sebagai bahan referensi atau rujukan untuk melakukan penelitian yang relevan.

\section{METODOLOGI PENELITIAN}

Penelitian ini di laksanakan di Lingkungan XI Rambung Putih Simpang Mancang Kelurahan Pekan Selesai Kabupaten Langkat. Waktu penelitian pada bulan September - Oktober tahun 2020. Jumlah populasi sebanyak 15 orang remaja berdasarkan rentang usia remaja antara 15-20 tahun (Data Lingkungan XI Rambung Putih Simpang Mancang Kelurahan Pekan Selesai Kabupaten Langkat, 2020). Sampel dalam penelitian ini yaitu 8 orang remaja yang diperoleh dengan teknik purposive sampling.

Jenis penelitian ini adalah penelitian eksperimen. Desain penelitian eksperimenyang digunakan dalam penelitian ini adalah one group pretest-posttest design (Sugiyono, 2018:110). Instrumen pengumpulan data dalam penelitian ini menggunakan kuesioner atau angket. Adapun indikator yang digunakan untuk menyusun angket tersebut yaitu (1) Penerimaan emosi, (2) Strategi regulasi emosi, (3) Keterlibatan perilaku bertujuan, dan (4) Kontrol respon emosi.

\section{HASIL DAN PEMBAHASAN}

Penelitian ini bertujuan untuk mengetahui pengaruh bimbingan kelompok terhadap regulasi emosi remaja. Sebelum kelompok sampel tersebut diberi perlakuan bimbingan kelompok, terlebih dahulu peneliti memberikan pretest berupa angket regulasi emosi dengan jumlah item sebanyak 32 item. Setiap remaja diminta untuk mengisi angket tersebut dengan jujur dan apa adanya. Setelah kelompok sampel diberi perlakuan bimbingan kelompok, selanjutnya peneliti memberikan 
posttest berupa angket regulasi emosi seperti posttest ditunjukkan pada tabel berikut. pada saat pretest. Nilai hasil pretest dan

Tabel 1. Nilai Pretest dan Posttest Regulasi Emosi Remaja

\begin{tabular}{cccc} 
No & Inisial Sampel & Nilai Pretest & Nilai Postest \\
\hline 1 & AD & 71 & 102 \\
\hline 2 & KA & 52 & 89 \\
\hline 3 & SA & 87 & 123 \\
\hline 4 & WS & 67 & 99 \\
\hline 5 & YD & 66 & 98 \\
\hline 6 & AI & 64 & 93 \\
\hline 7 & PT & 85 & 121 \\
\hline 8 & MR & 73 & 104 \\
\hline & Jumlah & $\mathbf{5 6 5}$ & $\mathbf{8 2 9}$ \\
\hline
\end{tabular}

Berdasarkan tabel di atas, dapat diketahui bahwa jumlah sampel yang mengikuti pretest dan posttest sebanyak 8 orang sesuai denganjumlah sampel yang direncanakan pada bab sebelumnya. Jumlah nilai total kemampuan regulasi emosi remaja sebelum dan sesudah diberi perlakuan bimbingan kelompok mengalami peningkatan yaitu 565 menjadi 829. Selanjutnya data tersebut akan di uaraikan satu-persatu pada subbab selanjutnya.

Data Pretest Regulasi Emosi Remaja

Tabel 2. Statistik Data Pretest Regulasi Emosi Remaja

\begin{tabular}{llc}
\multicolumn{1}{c}{ Statistik } & & Pretest \\
\hline $\mathrm{N}$ & Valid & 8 \\
\cline { 2 - 3 } & Missing & 0 \\
\hline Mean & 70.62 \\
\hline Median & 69 \\
\hline Std. Deviation & 11.3758 \\
\hline Minimum & 52 \\
\hline Maximum & 87 \\
\hline
\end{tabular}

Berdasarkan tabel diatas dapat dilihat bahwa data kelompok remaja sampel penelitian yang valid sebanyak 8 data, hal ini menunjukkan antara jumlah sampel dan data yang ada sudah sesuai. Nilai rata-rata regulasi emosi remaja sebesar 70,62. Median atau nilai tengah sebesar 69. Standar deviasi sebesar 11,37. Nilai minimum atau nilai terendah sebesar 52, dan nilai maxsimum atau nilai
Sebelum kelompok remaja pada sampel penelitian diberi perlakuan bimbingan kelompok, terlebih dahulu diberi tes awal (pretest) regulasi emosi untuk mengetahui kondisi regulasi emosi remaja sebelum diberikan bimbingan kelompok. Data statistik hasil pretest regulasi emosi kelompok remaja tersebut dapat dilihat pada tabel berikut: tertinggi mencapai 87.

\section{Data Posttest Regulasi Emosi Remaja}

Setelah kelompok remaja pada sampel penelitian diberi perlakuan bimbingan kelompok, maka selanjutnya diberi tes akhir (postest) regulasi emosi untuk mengetahui kondisi regulasi emosi remaja setelah diberikan bimbingan kelompok. Data statistik hasil posttest regulasi emosi kelompok remaja 
tersebut dapat dilihat pada tabel berikut:

Tabel 3. Statistik Data Postest Regulasi Emosi Remaja

\begin{tabular}{llc} 
& Statistik & Posttest \\
\hline \multirow{2}{*}{$\mathrm{N}$} & Valid & 8 \\
\cline { 2 - 3 } & Missing & 0 \\
\hline Mean & 103.62 \\
\hline Median & 100.50 \\
\hline Std. Deviation & 12.30 \\
\hline Minimum & 89 \\
\hline Maximum & 123 \\
\hline
\end{tabular}




\section{Jurnal Serunai Bimbingan dan Konseling \\ Vol 9, No. 2, Oktober 2020 \\ e-ISSN 2655-223X}

Berdasarkan tabel diatas dapat dilihat bahwa data kelompok remaja sampel penelitian yang valid sebanyak 8 data, hal ini menunjukkan antara jumlah sampel dan data yang ada sudah sesuai. Nilai rata-rata regulasi nilai tengah sebesar 100,50. Standar deviasi sebesar 12,30. Nilai minimum atau nilai terendah sebesar 89 , dan nilai maxsimum atau nilai tertinggi mencapai 123 .

\section{Uji Normalitas Data}

Hasil uji normalitas sebaran data penelitian menunjukkan bahwa data pretest dan posttest regulasi emosi memiliki sebaran data yang berdistribusi normal. Hal tersebut ditunjukkan oleh nilai signifikansi data pretest sebesar 0,979 sehingga nilai signifikansi yang didapat 0,979>0,05 dan nilai signifikansi data posttest sebesar 0,756 sehingga nilai signifikansi $0,756>0,05$. Berdasarkan nilai tersebut maka menerima kriteria pengujian bahwa data berdistribusi normal sebab nilai signifikan hasil perhitungan lebih besar dari 0,05 .

\section{Uji Linearitas Data}

Hasil uji lenearitas pada data hasil penelitian ini, diketahui bahwa nilai signifikansi sebesar 0,000 dimana nilai signifikansi tersebut menunjukkan kurang dari $0,05(0,000<0,05)$ sehingga memenuhi kriteria pengujian yaitu bahwa dua variabel dikatakan mempunyai hubungan yang linear bila signifikansi (linearity) kurang dari 0,05. Kemudian berdasarkan gambar 4.1 di atas terlihat bahwa sebaran data mengikuti garis linear, hal ini juga menunjukkan bahwa data hasil penelitian berbentuk linear.

\section{Uji Hipotesis Penelitian}

Hasil uji hipotesis menunjukkan bahwa nilai $\mathrm{t}$ hitung $=3,8$ sedangkan $\mathrm{t}$ tabel untuk jumlah sampel sebanyak 8 dengan tingkat kesalahan 5\% adalah 1,94. Sehingga nilai $t$ hitung lebih besar dari t tabel yaitu 3,8 $>1,94$

maka keriteria pengujian yang diterima adalah tolak Ho dan terima Ha, dengan demikian dapat dikatakan bahwa terdapat pengaruh bimbingan kelompok terhadap regulasi emosi remaja di Lingkungan XI Rambung Putih Simpang Mancang Kelurahan Pekan Selesai Kabupaten Langkat.

\section{Pembahasan Hasil Penelitian}

Berdasarkan hasil pengujian terhadap hipotesis maka hasil penelitian ini menemukan bahwa ternyata terdapat pengaruh bimbingankelompok terhadap regulasi emosi remaja di Lingkungan XI Rambung Putih Simpang Mancang Kelurahan Pekan Selesai Kabupaten Langkat. Hal tersebut ditunjukkan oleh nilai rerata regulasi emosi remaja sebelum diberikan bimbingan kelompok adalah sebesar 70,62 dan setelah diberikan bimbingan kelompok menjadi 103,62. Dengan demikian terdapat perubahan positif yang terjadi pada remaja di Lingkungan XI Rambung Putih Simpang Mancang Kelurahan Pekan Selesai Kabupaten Langkat. Dalam menganalisis data, peneliti menggunakan perangkat software SPSS, dimana dalam menganalisis data peneliti menggunakan uji $\mathrm{t}$ dengan tujuan untuk mengetahui pengaruh bimbingan kelompok dalam terhada regulasi emosi remaja.

Penelitian ini didukung oleh peneliti sebelumnya yaitu penelitian oleh Aisyah Lubis pada pada tahun 2017 dengan judul "Bimbingan Kelompok Dengan Teknik Sosiodrama Meningkatkan Regulasi Emosi Pada Remaja SMA di Kota Bengkulu". Tujuan penelitian Aisyah Lubis adalah untuk mendeskripsikan pengaruh layanan bimbingan kelompok dengan teknik sosiodrama terhadap regulasi emosi dalam interaksi remaja dengan teman sebaya. Metode penelitian yang digunakan dalam penelitian ini adalah metode eksperimen dengan pendekatan Pre Experimental Design. Alternatif pendekatan yang digunakan adalah the one group pretest posttest design. Populasi dalam 
penelitian ini adalah remaja kelas X IIS 5 SMA Negeri 3 Kota Bengkulu yang berjumlah 34 remaja. Penentuan sampel menggunakan teknik purposive sampling. Jumlah sampel adalah 10 remaja. Data hasil penelitian ini dianalisis menggunakan uji $z$. Hasil penelitian menunjukkan bahwa regulasi emosi meningkat setelah diberikan layanan bimbingan kelompok dengan teknik sosiodrama. Temuan hasil penelitian ini menunjukkan bahwa terdapat pengaruh layanan bimbingan kelompok teknik sosiodrama untuk meningkatkan regulasi emosi dalam interaksi dengan teman sebaya.

Hampir sama halnya dengan penelitian yang saya lakukan karena penelitian yang dilakukan oleh Aisyah Lubis ini mengkaji masalah regulasi emosi dan bimbingan kelompok yang dimana regulasi emosi remaja dapat meningkat dengan diberikannya layanan bimbingan kelompo. Layanan bimbingan kelompok yaitu layanan bimbingan dan konseling yang memungkinkan remaja memperoleh kesempatan untuk pembahasan dan pengentasan permasalahan yang dialaminya melalui dinamika kelompok. Dinamika kelompok adalah suasana yang hidup, yang berdenyut, yang bergerak, yang berkembang, yang ditandai dengan adanya interaksi antara sesama anggota kelompok. Layanan bimbingan kelompok merupakan layanan konseling yang diselenggarakan dalam suasana kelompok.

Pelaksanaan bimbingan kelompok dalam penelitian ini dilakukan sesuai dengan tahapantahapan bimbingan kelompok yang dikemukakan oleh Prayitno seperti dikutip Utomo (2018:29) yaitu tahap pembentukan, peralihan, kegiatan, dan pengakhiran. Dalam penelitian ini proses bimbingan kelompok dilakukan membagi sampel menjadi dua kelompok pada masing masing kelompok terbagi atas 4 orang. Pada tahap pertama dilakukan tahap pembentukan dan peralihan. Dalam tahap pembentukan peneliti melakukan pendekatan dengan remaja secara mendalam agar dapat berkembangnya dinamika kelompok. Pada tahap ini peneliti membangun keakraban dalam kelompok dengan saling memperkenalkan dirinya masing-masing dan tentang pribadinya masing-masing, seperti nama panggilan, hobi, cita-cita dan hal-hal yang disukai remaja sambil peneliti juga berupaya menghidupkan agar proses kegiatan bimbingan kelompok menjadi lebih menarik sehingga remaja dapat lebih leluasa, terbukaserta merasa bebas dalam mengeluarkan pendapatnya.

Kemudian dilanjutkan dengan tahap peralihan yaitu tahap menuju ketahap kegiatan, dalam tahap ini peneliti melihat kesiapan remaja untuk melanjutkan pada tahap berikutnya serta menjelaskan pengertian dan hal yang akan ditempuh pada tahap selanjutnya, seperti menjelaskan pengertian bimbingan kelompok, asas dalam bimbingan kelompok dan lain-lain. Setelah saling membahas tentang bimbingan kelompok saling membahas tentang kemampuan regulasi emosi seperti saling membahas tentang pengertian regulasu emosi tersebut, namun anggota kelompok diminta aktif seperti dalam mengemukakan pendapatnya masing-masing. Kemudian dalam tahap kegiatan setiap anggota diminta mengungkapkan masalah-masalah apa saja yang merupakan atau terkait dengan regulasi emosi dan dari sekian banyak masalah yang di ungkapkan oleh masing-masing anggota maka kelompok pertama tersebut membahas tentang emosi muncul ketika mendapat sindiran melalui sosial media. Setiap anggota menyampaikan apa saja yang biasa di komentari dalam maslah ini seperti menyindir karena mereka tidak menyukai teman mereka tersebut, menyindir karena masalah dalam pergualan sehari-hari dan menyindir karena hanya masalah sepele lainnya, setelah melakukan banyak pembahasan tentang menyindir teman maka 
kemudian pemimpin kelompok melakukan selingan dengan membuat games yaitu games yang setiap anggota kelompok menghitung angka satu sampai enam dan setiap angkaangka tertentu diminta agar mereka tidak menyebutkan angka tersebut tetapi diminta agar menepuk tangan mereka sekali.

Tujuan games tersebut agar melatih kefokusan dan agar lebih santai dalam mengemukakan pendapat, setelah melakukan games maka kembali ke pembahasan dan

kemudian anggota kelompok diminta mengemukakan kesimpulan tentang apa yang telah dibahas. Selanjutnya pada pertemuan kedua peneliti langsung ketahap kegiatan dan pembahasannya di lanjutkan dengan strategi regulasi emosi, tahapan regulasi emosi, aspekaspek regulasi emosi dan faktor-faktor regulasi emosi, serta diselingi dengan permainan agar anggota kelompok tidak merasa tegang dan bosan. Setelah semua tahap selesai, selanjutnya peneliti melakukan posttest dengan angket regulasi emosi yang sama pada saat pretest. Berdasarkan penelitian yang dilakukan, dapat di simpulkan bahwa bimbingan kelompok berpengaruh terhadap regulasi emosi remaja di Lingkungan XI Rambung Putih Simpang Mancang Kelurahan Pekan Selesai Kabupaten Langkat.

\section{KESIMPULAN}

Berdasarkan hasil penelitian mengenai pengaruh bimbingan kelompok terhadap regulasi emosi remaja di Lingkungan XI Rambung Putih Simpang Mancang Kelurahan Pekan Selesai Kabupaten Langkat, maka dapat diambil kesimpulan yaitu terdapat pengaruh bimbingan kelompok terhadap regulasi emosi remaja di Lingkungan XI Rambung Putih Simpang Mancang Kelurahan Pekan Selesai Kabupaten Langkat. Hal itu ditunjukkan dengan besarnya koefisien nilai $\mathrm{t}$ hitung dan $\mathrm{t}$ tabel yaitu 3,8 $>1,94$.

\section{DAFTAR PUSTAKA}

Anggreiny, Nila. (2014). "Rational Emotive Behaviour Therapy (REBT) untuk Meningkatkan Regulasi Emosi pada Remaja Korban Kekerasan Seksual". Tesis. Magister Psikologi Profesi Kekhususan Klinis Anak : Universitas Sumatera Utara.

Arikunto, Suharsimi. 2018. Prosedur Penelitian: Suatu Pendekatan Praktek. Jakarta: Rineka Cipta.Desmita. 2010. Psikologi Perkembangan Peserta Didik. Bandung: Remaja Rosdakarya.

Diananda, Amita. 2018. "Psikologi Remaja Dan Permasalahannya". Jurnal Istighna. Volume 1 Nomor 1.

Fitriani, Yulia \& Alsa, Asmadi. 2015. "Relaksasi Autogenik untuk

Meningkatkan Regulasi Emosi pada Remaja SMP”. Journal of Psychology, Vol.1, No. 3.

Hartinah, Siti. 2017. Konsep Dasar Bimbingan Kelompok. Bandung: Refika Aditama.

Herlina. 2016. Peranan Keluarga Dalam Mencegah Tindak Tuna Sosial Oleh Remaja di Desa Cadasari Kec. Cadasari Kab. Pandeglang. Jurnal Eksistensi Pendidikan Luar Sekolah (E-Plus) Vol.1.No.1.

Lubis, Aisyah. 2017. "Bimbingan Kelompok Dengan Teknik Sosiodrama Meningkatkan Regulasi Emosi Pada Remaja Sma Di Kota Bengkulu”. Jurnal Ilmiah Bimbingan dan Konseling, Volume 1 Nomor 1 FKIP Universitas Bengkulu.

Rahayu, Fanny Septiany. 2013. "Gambaran Sikap Sosial Dalam Pergaulan Remaja Ditinjau Dari Perbedaan Etnis". Jurnal Bimbingan Dan Konseling Volume 2 Nomor 1.

Rusman. 2009. Manajemen Kurikulum. Jakarta: Raja Grafindo Persada. 
Simarmata, Sari Wardani dan Citra, Yulia. 2020. "Kecanduan Internet Terhadap Keterampilan Sosial Di Era Generasi Milenial". Jurnal Serunai Bimbingan dan Konseling Vol 9, No. 1. 